\title{
DISPLACEMENT, MEMORY, AND POSTMEMORY IN THREE NOVELS FROM Brazil, Argentina, and Chile*
}

\section{Deslocamento, memória e pós-memória em três romances do Brasil, Argentina e Chile*}

\author{
Cristina Ferreira Pinto-Bailey ${ }^{1}$ \\ ${ }^{1}$ Independent scholar. Lexington, Virginia, EUA. \\ E-mail: cristinalexbrasil@gmail.com
}

EDITOR-CHEFE:

Rachel Esteves Lima

EDITOR EXECUTIVO:

Regina Zilberman

SUBMETIDO: 05.10 .2021

ACEITO: 10.11 .2021

\section{COMO CITAR:}

PINTO-BAILEY, Cristina Ferreira. Displacement, memory, and postmemory in three novels from Brazil, Argentina, and Chile. Revista Brasileira de Literatura Comparada, v. 24 , n. 45 , p. $65-76$, jan./ abr., 2022. doi: https:// doi.org/10.1590/2596$304 \times 20222445 \mathrm{cfpb}$

\section{ABSTRACT}

This essay examines issues of displacement, exile, and non-belonging, and their impact on a subject's sense of identity, in three novels by South American women writers: Ana Maria Machado (Brazil), Griselda Gambaro (Argentina), and Alejandra Costamagna (Chile). Furthermore, the essay discusses how memory and postmemory are fundamental elements in narratives in which the narrator and/or protagonist set out to write and rewrite self-identity, family and national histories.

KEYWORDS: displacement; exile; Ana Maria Machado; Griselda Gambaro; Alejandra Costamagna.

\section{RESUMO}

Este ensaio examina questões relativas a deslocamento, exílio e não-pertencimento, e seu impacto sobre a constituição da subjetividade em três romances de escritoras sul-americanas: Ana Maria Machado (Brasil), Griselda Gambaro (Argentina), e Alejandra Costamagna (Chile). Ademais, o ensaio discute como a memória e a pós-memória representam elementos fundamentais em narrativas nas quais a voz narrativa e/ou a protagonista propõe-se a escrever e reescrever sua subjetividade e as histórias de família e da nação.

PALAVRAS-CHAVE: deslocamento; exílio; Ana Maria Machado; Griselda Gambaro; Alejandra Costamagna.

\footnotetext{
* This essay draws in part from my article "Women, Memory, Nation: Writing Identities in Three Latin
} American Novels”. Symposium: A Quarterly Journal in Modern Literatures 68.4 (2014): p. 203-17. http:// www.scielo.br/rblc https://revista.abralic.org.br 
I $\mathrm{n}$ this essay, I will discuss three contemporary novels by women writers from Brazil, Argentina, and Chile that represent and problematize issues of displacement, exile, non-belonging, and self-identity. The novels are O mar nunca transborda (1995) by Ana Maria Machado (Brazil, 1942); El mar que nos trajo (2001) by Griselda Gambaro (Argentina, 1928); and El sistema del tacto (2018) by Alejandra Costamagna (Chile, 1970). The examination of works by writers from different generations will offer a brief but insightful study into geographic and affective displacement, political and psychological exile, and feelings of non-belonging as recurrent themes in women's fiction from the region. At the same time, this study will highlight aesthetic and political differences that reflect each author's and her characters' positionality within history. Two aspects stand out in my discussion of the novels: one, how Gambaro and Machado explore the idea of self- and national identity, while Costamagna's novel raises and, in turn, problematizes the possibility of a postnational identity. Furthermore, I will also address here the fundamental role memory and postmemory play in each protagonist's life story as a common element in these narratives. ${ }^{1}$

\section{DISPLACEMENT, THE NATION, AND SELF-IDENTITY}

Both Gambaro's and Machado's novels weave together history, fiction and autobiography, and reflect a preoccupation with country and society. O mar nunca transborda and El mar que nos trajo each presents a vision of the nation that foregrounds the participation of specific groups in the project of nation building, even if they were excluded from the hegemonic national narrative. Machado and Gambaro write the nation by narrating stories lived on the margins of the dominant discourse and of official history-History with a capital " $h$," which generally portrays the nation as a unified entity through the representation of public, officially vetted, factual events. The Brazilian and the Argentinean authors, on the contrary, problematize the idea of the nation as a fixed and unified concept, and underscore what Homi Bhabha has called the "ambivalence that haunts the idea of the nation" (BHABHA, 1990, p. 1).

Machado's and Gambaro's novels highlight and embrace the multiethnic and multicultural heritage of their countries, and re-write the "major narrative" of the nation through "minor narratives," or the micro history of previously invisible segments of their societies through the life stories of everyday individuals whose experiences may seem irrelevant in the large scale of national history. Furthermore, these novels represent history not as a sum of finalized public events, but rather "history in the process of being made" (BHABHA, 1990, p. 3), a process that is only provisionally complete in the reading that each new generation makes of its past and of its ancestors' experiences, their memories and postmemories. In these novels, history becomes a polyphonic narrative continuously actualized by those who narrate and those who read it, while the idea of national identity is seen through new perspectives that problematize chauvinistic concepts of the nation.

As these novels write not only national identity but also self-identity, the understanding of history as a process always in the making is coherent with the conceptualization of national identity and self-identity also as continuous processes that may reach some stability only to be again destabilized or called into question. Identity is achieved through language, "constituted in discourse" (SMITH;

1 In Family Frames: Photography, Narrative, and Postmemory, Marianne Hirsch explains "postmemories" as memories of events lived by previous generations that affectively and otherwise impact those in the present trying to recover and make sense of the past. Hirsch further discusses postmemory in later works, most notably in The Generation of Postmemory. 
WATSON, 2010, p. 206), in the narrative act through which the subject gives meaning to the pastto history and society, to memories and community. The narrative act may thus be understood as a dialogical enterprise or "the meeting place of diverse voices" (BROOKS, 1994, p. 78), the intersection where memory, history and stories come together to be actualized in the experience of the subject. Many different factors - such as class, race, gender and geographical location - shape the subject's sense of self-identity and, dialectically, the notion of national identity. This is what Bhabha describes as the "ambivalence" of the idea of nation: the ambivalence and fluidity of one's identification with the nation shapes his or her sense of national identity, which in turn bears upon self-identity. In El sistema del tacto, in turn, national history is only alluded to marginally and sparsely. That is not to say, however, that national identity does not play into the protagonist's sense of self, her feelings of non-belonging, and her ambivalence toward her place of birth. Ania, the protagonist, is a Chilean woman in her late thirties whose father is from Argentina and left the country for political reasons: "... el señor Coletti, el que se volvió chileno" (COSTAMAGNA, 2018, p. 72). Despite spending every childhood summer at her grandparents' home in the Argentinean town of Campana, Ania is regarded there as the Other; just like her father, the one who left his home country to become an alien to his old neighbors and relatives (Ania is labeled "la chilenita," despite her family roots in Argentina).

El sistema del tacto is less concerned with rewriting national history than the previous two novels, even if the question of national identity and belonging runs implicit through the narrative. Costamagna's novel presents itself, instead, as an exploration of the many factors that shape the unstable subjectivity of the protagonist and other characters and their sense of displacement. O mar nunca transborda and $E l$ mar que nos trajo, on the contrary, make explicit the authors' concern with narrating national history, even if they do so through a subjective, partial and self-reflexive perspective of the past: in Gambaro's novel, we have few but clear snapshots of Argentina's historical events interwoven with her characters' personal tragedies, while Machado acknowledges various historical sources at the beginning of her book. As fictional narratives, however, these works stand as alternative registers of history, presenting a picture of the nation as "una entidad en movimiento que además puede no tener una sola figura sino tantas como sujetos sociales que la experimentan y piensan” (CORNEJO POLAR, 1992, p. 140-41). The ever-increasing flux of populations across geopolitical borders, for political, economic, and more recently, environmental reasons, adds to the instability of the concept of nation, impacting also how individuals come to understand their own sense of identity; movement and displacement become thus key factors in defining identities across the American hemisphere.

While the widespread contemporary movement of individuals across national boundaries in a globalized world has motivated a growing number of recent critical studies on subjectivity and national identity shaped by migration, exile and displacement, these phenomena are certainly not new. In $O$ mar nunca transborda and El mar que nos trajo the nation as an "entidad en movimiento" emerges from the articulation of several elements: one, memory, its selective character, and the role it plays in the reconstruction of the past; two, self-referentiality embedded in the fictional lives of the characters; and, three, the thematic focus on migration, exile, displacement and dislocation. Additionally, the insertion of aspects of each author's biography within these fictional life stories helps shape history not only as something that happened, but also, and more importantly, as an ongoing narrative that encompasses the present time, thus stressing the relevance of the past for individuals today. It should 
be noted that Costamagna's novel also presents an autobiographical referent, for the author herself was born in Chile to Argentinean parents who had left their country in 1967 to escape the dictatorship of Juan Carlos Onganía (1966-70). Whether the novel was inspired by autobiographical events is irrelevant; noteworthy is how the narrative conveys a sense of urgency to reconstruct a family's past and understand one's own place in the world.

O mar nunca transborda and El mar que nos trajo contest the concept of nation and national identity by bringing to the foreground characters who have been dislocated by migration, globalization, social and political powerlessness, as well as by the official historiography that had rendered them voiceless, as invisible or minor actors. These works therefore highlight "the subjective nature of national identity" (HUNSACKER, 1999, p. 4), underscoring the idea that the nation is indeed an "imagined community," to use Benedict Anderson's famous phrase, a community constituted by memory and by micro histories, and very often at odds with "the dominant forms of national identity" (HUNSACKER, 1999, p. 5). The possibility of building an "imagined community" acquires an urgent dimension for Costamagna's protagonist, as I will discuss later.

$O$ mar nunca transborda and El mar que nos trajo bring into a sharper focus fragments of their nations' histories while blurring the distinction between public and private, fiction and truth. They achieve a historical vision of the nation through micro histories, family sagas and individual genealogies, with an emphasis on personal experiences and marginalized perspectives. These are hybrid narratives: historiographic novels but also variations of life stories, fictional autobiographies or autobiographical fiction. Whereas in the nineteenth and part of the twentieth centuries these autobiographical narratives were most often narrated in the first person, today such stories often present a "slippery" narrative viewpoint, with the "I" disguising itself behind a third-person narrator. The ex-centric perspective of their narrators and the hybrid nature of these texts, which locate them at the intersection of history, fiction and life story, characterize them as examples of "autography," a term coined by feminist critic Jeanne Perreault to describe narratives of the self that challenge the limits and practice of the autobiographical genre, through "an ongoing negotiation of the shifting boundaries of the 'I' and the 'we," and that reject any "notion of autobiography as a master narrative of the bourgeois subject" (SMITH; WATSON, 1998, p. 37).

\section{STORIES OF THE SEA: FAMILY SAGAS, FICTIONS OF DISPLACEMENT}

Across the western hemisphere, the postmodern novel has shown a renewed interest in history, "a new desire to think historically, but to think historically [...] critically and contextually" (HUTCHEON, 1988, p. 366), and at the same time a redoubled interest in narratives of the self, with the increased publication of fictional autobiographies, autobiographical fiction, and other self-reflexive forms, such as the memoir and the bildungsroman. As Smith and Watson state, "stories of the self, family, or community [...] illuminate the legacies of larger historical formations" (p. 29). The Latin American postmodern novel, specifically, is, "resolutely historical and inescapably political" (WILLIAMS, 1995, p. 17), and has been informed by a "search for cultural origins" (WILLIAMS, 1995, p. 128). Not by coincidence, the sea or the ocean is a leitmotif in Gambaro's and Machado's novels, appearing as a metaphor for the origins and formation of the nation and for the characters' displacement, and as a symbol of the hope 
and possibility of a new beginning and a better life; thus, the sea is associated with the development of the protagonists' sense of identity.

In $O$ mar nunca transborda and in El mar que nos trajo the search for origins may have derived from the need to remember in the aftermath of the civil-military dictatorships that ruled those countries through the mid 1980's. While both novels were published after democracy had been restored in Brazil and Argentina, they manifest an extension of a cultural-political movement that sought to deal with the countries' political and personal trauma through memory, remembrance, and the preservation of the past, despite the Brazilian and Argentine governments at the time urging for reconciliation, or in other words, urging their societies to "forgive and forget." And if they were expected to forget in the name of an imposed national "reconciliation," remembering became then an act of resistance. Memory represents a means to understand and heal the wounded nation, and as Amy Kaminsky explains, the look toward the past responds to "the need to reestablish a national community" after the nation had been torn apart by a dictatorship and its consequences (KAMINSKY, 1999, p. 21). Therefore, while during the dictatorships literature had been an instrument to denounce the abuses of the military regimes_-assuming it could avoid censorship_it later became a means not only to remember and register the recent history, but also to remember and rewrite a more distant history, a way of returning to the country's origins and to other historical periods formative of the national identity.

Machado as well as Gambaro engage in a "dialogue about the past" (LEVINE, 2008, p. 25) as a way of understanding Brazil's and Argentina's past and present: their history and national identity. Both authors' concern with national history and identity has also been informed by their years in exile. As Annette H. Levine states about Gambaro and other contemporary Argentine writers, "the experience of exile and the harsh reality of the Dirty War cause them to reevaluate their past notions of Argentina as home, as national identity" (p. 23). This is also true of Machado, who left Brazil for Europe in 1969 after being arrested and then released by the military, returning to Brazil at the end of 1972. Gambaro, in turn, left Argentina in 1977 after her novel Ganarse la muerte (1976) was banned, and lived in Spain until 1980. Levine considers that Gambaro experienced a "double exile," not only in Spain but also, before then, an internal exile in Argentina, when she was unable to publish because of censorship, and felt disconnected from her public and prevented from expressing herself (LEVINE, 2008, p. 77). Levine's point is a reminder that some may experience displacement or a sense of not belonging in their own homeland. Some, like Machado and Gambaro, may have felt psychologically imprisoned or exiled in their own countries due to political censorship, persecution and insecurity, while others have experienced and continue to experience the same feelings due to economic oppression, racism or other forms of discrimination.

Such experiences of exile and displacement are central to $O$ mar nunca transborda and El mar que nos trajo. The Brazilian novel is set in the early 1990's; the protagonist, Liana, is a journalist working for a magazine in London, where she has been living for a year. The reason for her being in London is never explained, but the narrative often describes the protagonist's "cultural exile" (MACHADO, 2008, p. 23) and deep sense of displacement and nostalgia for Brazil. The novel alludes briefly to the dictatorship, and there are many references to the social and economic disarray in the post-dictatorship period: the widening economic gap between rich and poor, urban violence and police abuses, and the lack of basic civil rights that affects a large segment of the population. These many allusions and 
conversations about recent developments in Brazil often take place between Liana and her Brazilian boyfriend Tito-himself a former street kid — and explain why so many chose to leave Brazil at that time to face displacement and marginalization as immigrants in other countries. Tito's stance on life and society-Brazil, London, his and Liana's social and cultural displacement, their bosses, nepotism at work, etc.-is frequently sharp and even cynical. As an Afro-Brazilian, Tito represents the perspective of Blacks in contemporary Brazilian society (VIEIRA, 2004, p. 49) and allows Machado to address (albeit briefly) the problem of racism and economic inequality in Brazil today.

To relieve her nostalgia for home and her sense of non-belonging, Liana recreates the history of Manguezal, a town on the coast of the State of Espírito Santo, from the very first years of Brazil's colonization by the Portuguese in the sixteenth century. Manguezal is a micro-representation of the nation's origins and represents also Liana's own origin, for it is where she had spent her formative years. ${ }^{2}$ The novel thus presents two stories, or a story within a story: the story of Liana; and the story of Manguezal and its inhabitants, a narration of Brazil's history told through the micro histories of the indigenous people, Portuguese, Africans and, later, other European immigrants who settle the Espírito Santo coast. The two stories frequently serve as counterpoints to each other; for example, Liana and Tito discuss the Candelária massacre immediately following a chapter of Liana's narrative in which she describes the massacre of some of Manguezal's inhabitants by the Dutch in the seventeenth century (MACHADO, 2008, p. 110-13). At the end of the novel, the history of Manguezal/Brazil and Liana's personal story converge when Liana leaves London to go back to Manguezal, thus bringing together past and present: memory, postmemories and current reality.

Liana's narrative of Manguezal's history is in some respects a utopian recounting of the national history and identity, with Manguezal standing as an Edenic place on Earth where people of different races and origins live together in harmony. O mar nunca transborda also contests José de Alencar's Iracema (1865), in that Machado's novel does not ignore the African matrix of Brazil's ethnic identity, but rather highlights the historical role Africans have played in the formation of national identity. Liana's narrative presents a wide portrait of the nation in which Indigenous people, Africans, Europeans and, soon, mestizos hold equal status. Her characters are common men and women, and the story/history she recreates is made up of "pequenas refregas e escaramuças [...]. Sem nenhuma importância para a História" (MACHADO, 2008, p. 107), instead of great feats and battles. The author is concerned not with the great, powerful names of History, but rather with how everyday people, seemingly powerless individuals, make history and how they are affected by it. Additionally, the author emphasizes women's active participation in historical developments and in the construction of national identity. As is usual in Machado's fiction, the novel's female characters are strong and determined women, nurturers but at the same time fighters, leaders of the community and engenderers of a new mestizo nation, a new people - the Brazilian people.

Liana writes a national narrative from the perspective of her own displacement in London; she represents the contemporary global subject, displaced, "fronteiriço," a subject lacking a "stable anchorage" (HALL, 1992, p. 274). Facing in London the absence of a stable reference point to support her sense of Brazilianness, the protagonist re-creates her family's origins by weaving together the stories heard from

2 Machado herself spent long periods of time during her childhood in her grandparent's house on the coast of Espírito Santo. The village of Manguezal in $O$ mar nunca transborda is a fictional representation of Manguinhos, where the author's grandparents had their home. 
her grandmothers and other family members. Thus, instead of looking to official historical documents as sources of knowledge, Liana prefers stories, micro histories passed down orally through generations. Machado herself based her novel on historical research and on stories she heard as a child, weaving together memory, history and fiction. The national identity she constructs is located not necessarily within the country's geopolitical limits, but rather on the shifting space of the capixaba beach sands and of the Atlantic Ocean. Therein emerges an "imagined community", a nation as embodiment of cultural and affective values, symbols and expressions, which will become Liana's reference point and anchor, the snug harbor to which the decentered and displaced subject yearns to return.

The longing of a return, the nostalgia of the sea, of the ancestors' motherland, of one's origins, are leitmotifs in Gambaro's El mar que nos trajo. Its epigraph, by Italian poet Salvatore Quasimodo, reads in part: "di me un'eco di memoria, / come quell buio murmure di mare" (an echo of memory, / like the dark murmur of the sea), which underscores the connection between memory and the sea, and points to the ocean as a symbol of origins, of beginnings and hope, but also of the unknown and of uncertainty.

Gambaro's novel begins in the year 1889 when Agostino, a nineteen-year-old Italian immigrant, arrives in Buenos Aires from Genoa, and describes events that take place in Argentina and Italy through the period immediately following World War II. ${ }^{3}$ Agostino, a fisherman from the Island of Elba, finds work in a boat bringing immigrants to South America and upon disembarking in Buenos Aires falls in love with another Italian immigrant and decides to stay in the Argentine capital. The couple takes up residence in a "casa de inquilinato," a tenement house, where their daughter Natalia is born. Thus begins a family saga that encompasses the two sides of the Atlantic Ocean, for Agostino is later forced to leave Natalia and her mother behind in Buenos Aires and return to Elba, where he will have a son with his legal wife. However, the saga never reaches a conclusion, for it includes the present day and the narrator, whose narrative weaves together stories she had heard as a child, told around the dinner table. Rather, this family saga continues in the lives of contemporary and of future generations who will carry on the task of constructing the nation and shaping national identity.

Gambaro privileges oral stories rather than the official historiography as a source of both family and the nation's history. Her novel focuses on the story of several generations of women and their struggle for survival, from the first decades of the twentieth century through the period immediately following the Second World War. Through their micro histories, the author paints a portrait of the nation that does not privilege Argentina's famous Río de la Plata-where Spanish exploration and colonization began - or any national myth inscribed in the official discourse, but rather the ocean, which represented for the poor immigrant the promise of a better life. Once on land, however, the immigrant finds those promises broken, and the ocean becomes associated with the nostalgia of a life

\footnotetext{
3 Agostino's arrival in 1889 places him among the more than four million Italian immigrants who arrived in Buenos Aires between 1870 and 1920, a mass immigration encouraged by Argentina's federal government, as stated in the country's Constitution of 1853. Argentina, much as Brazil during the same period, sought to solve its modernization problems by subsidizing the immigration of European workers, while Brazil encouraged European immigration also as a reaction to the "scientific racialist" ideas that circulated in Europe during that time.
} 
that, seen through the haze of memory, seems easier and better than the life of poverty and oppression in the New World.

Gambaro recovers not only the presence of Italian immigrants in Argentine history, but also her own family history, as her parents were Italian immigrants from Genoa. The yearning for the ocean experienced by Natalia, whose parents crossed the Atlantic in search of a better life, but who herself never got to see more than the port of Buenos Aires, represents the character's longing for a lost father, but may also be seen to represent the author's nostalgia for her own origins. It is also a symbol of those ancestors who participated in the formation of Argentina's national identity, but who remained anonymous in the annals of history. The narrator, identified in the very last paragraph of the novel as Natalia's niece, ties the events of the past to the contemporary period, as a witness who relives memories and post-memories of several generations of her family.

El mar que nos trajo is a family saga that tells the story/history of a large and important segment of Argentine society and the national history from the "lesser" perspective of Italian immigrants and first generations of their descendants. By focusing on the struggles, poverty and isolation of the immigrants - many of whom never learned Spanish — in their new country, the author contradicts the idea that the early twentieth century was a period of hope and great expectation in the construction of Argentina's national identity (CHEADLE, 2007, p. 13-14), when "a sense of identification was possible because of a near-universal literacy, political enfranchisement, and relatively secure employment" (Beatriz Sarlo, qtd. in CHEADLE, 2007, p. 15). The characters in El mar que nos trajo, on the contrary, suffer the oppression of barely having enough to eat despite working long days in often-subhuman conditions, the scorn and abuse of patrons and landlords, and the humiliation of their linguistic inability to communicate. They represent thus a segment of Argentine society excluded from the official, optimistic image of the nation in the first decades of the twentieth century.

As a family saga, the 156-page-long novel is not typical of the genre. Here Gambaro chooses brevity, focusing on emblematic moments in the characters' lives that underscore their sense of displacement, isolation, poverty and disenfranchisement, while a few historical events briefly sketch national and world political developments: the anarchist movement in the early 1900's; the killing in Argentina of protesting workers during the "Tragic Week" in 1919; World War II; and the government of Juan Perón. These sparse historical events described in brief but emblematic scenes are especially relevant because of their impact on the characters' personal lives, while the characters, in turn, illustrate the plight of many other individuals living similar experiences of social, cultural and economic exclusion.

\section{OVER THE ANDES AND ACROSS THE OCEAN: BUILDING A SENSE OF BELONGING THROUGH MEMORIES AND POSTMEMORIES}

"Postmemory," according to Marianne Hirsch, "describes the relationship that the 'generation after' bears to the personal, collective, and cultural trauma of those who came before-to experiences they 'remember' only by means of the stories, images, and behaviors among which they grew up" (HIRSCH, 2012, p. 4). In her work, Hirsch examines the postmemories of children of survivors of the Holocaust, but the concept applies to other contexts as well. Postmemory is certainly one of the factors that leads the narrator in Gambaro's El mar que nos trajo to tell the story of Agostino, Natalia, and her family. At the same time, both Gambaro and Machado lived through and wrote about the civil-military 
dictatorships in their countries. These periods of extreme political violence and state terrorism have generated a substantial and important body of fictional and memorialist literature written by those who lived and witnessed those events. More recently, a growing number of important books of fiction by authors who belong to the "generation after," as Hirsch calls them as, have addressed the dictatorships and their aftermath through the examination of memories and postmemories. Among such authors are, for example, Argentine Claudia Piñeiro (b. 1960), Adriana Lisboa (b. 1970), and Julián Fuks (b. 1981), the latter two from Brazil. Alejandra Costamagna also belongs to this generation and, like Fuks, was born to parents who left Argentina for a neighboring country during a dictatorship-Costamagna's parents in 1967, and Fuks's during the Dirty War (1976-1983).

Costamagna set out to write El sistema del tacto as a non-fictional narrative to document the stories of Italian immigrants who settled in Argentina's provinces, among them the author's grandparents. However, she soon found out that a purely documentary narrative would not suffice to encompass these immigrants' micro histories: “... me fui dando cuenta de que la documentación pura y dura era igualmente una ilusión. Que no podía contar el pasado tal como había sido, que no podía restituirlo, que tampoco me interesaba hacerlo a fin de cuentas, y que inevitablemente iba a tener que proyectar, imaginar y poner en duda las versiones de lo que recogía como la verdad de los hechos" (Costamagna, 2019 , n.p.). The writer's statement corroborates Hirsch's that "Postmemory's connection to the past is... mediated... by imaginative investment, projection, and creation” (HIRSCH, 2012; p. 4). It is through the fictionalization of a family's history that the writer registers the presence of her ancestors within national history and the lives of those who, like Costamagna, were impacted by their elders' displacement - be it across the South American continent or across the Atlantic. Costamagna's fictional project in El sistema del tacto fulfills one important task of storytelling; in the words of Brazilian writer Noemi Jaffe: one tells the story of their elders "so that they might learn something, so that they might understand their memory and their forgetting", while inscribing their micro history "onto the body of the world" (JAFFE, 2016, p. 96).

Ania, Costamagna's protagonist, is a Chilean woman in her thirties who travels to Argentina at her father's request, to represent him at his cousin Agustín's funeral. Like the author, Ania is the daughter of Argentine exiles, her father a leftist who is forced to leave Argentina because of his political views, and this coincidence lends the novel autographical elements. The novel barely mentions the protagonist's mother, focusing instead on Ania's paternal side of the family and on her own sense of displacement and inability to fit in, which may be understood as a consequence of the family's foreignness: she is fired from her job as a teacher because she fails to adhere to the school's standards and expectations; walks other peoples' dogs and house sits to make money; needs to take medication so she can sleep at night; and has a boyfriend twenty-five years her senior. Her relationship with her father is flawed, if not completely estranged, and Ania feels out of place at his home, where the walls are lined with photos of his second wife's family and none of herself, as if the paternal home were inhabited by a "genealogía ajena" (COSTAMAGNA, 2018, p. 26) that denied her own existence.

Ania's return to Campana, her father's home town where she had spent her childhood summers, elicits a series of recollections about the annual trips she had made with him across the Andes, her experiences at her grandparents' home and in town. Among her memories, the image of Nélida, her great-aunt, stands out in Aria's mind. Nélida, Agustín's mother, is an immigrant from Italy who, as a 
young woman, during the Second World War, was sent to Argentina by her parents against her will. During her summers in Campana, Ania would surreptitiously leave her grandparents' bedroom where she had to endure forced "siestas" and go to the house next door where she sat for long periods of time in Nélida's dark room, listening to the old woman tell stories of Italy and the war. At that point, Nélida had already "lost her mind" (COSTAMAGNA, 2018, p. 43) and had tried to commit suicide. Memories of other people talking about the Italian woman and her "disgrace" mix with Ania's own memories of Nélida's strange behavior and with postmemories, in other words, with Nélida's memories of events she lived and witnessed in the old country. Memory is thus a fundamental element in the novel's structure, while displacement, estrangement and non-belonging pervade the text. This is expressed not only from Ania's viewpoint, but also through the perspectives of Nélida and of Agustín. In fact, the novel's opening chapter relates Agustín's stream of consciousness, as he thinks of Ania, "la chilenita," and his wish that she could save him from a meaningless life: "Que la chilenita lo salve. Que lo salve de ahí, que le abra las puertas, que lo haga cruzar el mar si es necesario, que le diga que... la vida es otra cosa. Pero la niña es una niña y no puede cambiar la historia" (COSTAMAGNA, 2018, p.15). The author thus weaves a polyphonic and fragmented narrative in which chapters focusing on Agustín alternate with others centered on Ania. The novel also presents a hybrid character, as the narrative is interspersed with letters, postcards and photos Nélida wrote while visiting Italy; pages from a 1913 manual for Italian immigrants; excerpts from popular horror fiction; Agustín's typing lessons; and other extraliterary documents. All these various sources, together with Ania's impressions during her current visit and her memories and postmemories, compose the characters' micro histories, while offering sparse glimpses into Argentina's history.

During Ania's childhood, Nélida must have seemed to her quite an enigmatic and fascinating figure. To the reader, however, it eventually becomes clear what the Italian great-aunt and an adult Ania have in common: both women are displaced subjects, seen as strangers, as the Other, even by their own relatives, their difference announced by language, by their accent, among other marks, while the alienation that both women experience takes on an extreme form in Nélida's madness. Ania, in turn, "no sabe exactamente quién es" (COSTAMAGNA, 2018, p. 73) but, by recovering Nélida’s history and piecing together their family's past, she is able to plot her own. In a sense, El sistema del tacto posits the possibility of a postnational identity, for the issue of national belonging and how it shapes one's sense of self becomes a moot point in Ania's case. Rather, a more important question the novel raises is how the exile of one generation may affect subsequent generations. The nation thus seems to have lost any meaning to become, more than ever, an unstable, vague, and even irrelevant concept. Torn between two countries and belonging to none, Ania's identity is shown as always in process, always incomplete, lingering between the two geopolitical spaces on either side of the Andes, but also longing for a country across the ocean, which she only knows through postmemories. Ania will find a sense of belonging only in the imagined community she builds on an intuited commonality between her, Nélida and Agustín; a community brought together by their shared feelings of displacement, nonbelonging, and alienation. 


\section{CONCLUSION}

The three novels here examined narrate the impact of exile, immigration, geographic and cultural displacement on an individual's subjectivity, connection to the past and to a community. They are narratives that tell of the crossing of borders that are not only geographic but also, and most importantly, affective borders. $O$ mar nunca transborda, El mar que nos trajo and El sistema del tacto also render problematic the national narrative and a chauvinistic understanding of identity and belonging. As Elizabeth Montes Garcés states in Relocating Identities in Latin American Cultures, "identities can no longer be tied to national boundaries [...], so they have to be found in a decentered cultural space" (8), or within imagined communities that traverse generations. In this regard, memory and postmemory are the fundamental sources of these narratives, as they uncover and probe the past to reveal its relevance in the understanding of the present, of one's sense of self and belonging.

\section{REFERENCES}

ANDERSON, Benedict. Imagined Communities: Reflections on the Origin and Spread of Nationalism. 2 ed. rev. and extend. London, New York: Verso, 1991.

BHABHA, Homi. Introduction: Narrating the Nation. In: BHABHA, Homi (org.) Nation and Narration. London; New York: Routledge, 1990. p. 1-7.

BROOKS, Peter. The Storyteller. Psychoanalysis and Storytelling. Cambridge, Mass.; Oxford, UK: Blackwell, 1994.p. 76-103.

CHEADLE, Norman. Cities and Identities at the Turn of the Twentieth Century. In: GARCÉS, Elizabeth Montes (org.) Relocating Identities in Latin American Cultures. Calgary, Alberta: Calgary UP, 2007. p. 13-33.

CORNEJO POLAR, Antonio. La "Invención” de las naciones hispanoamericanas. In: ZAVALA, Iris M. (org.). Discursos sobre la 'invención' de América. Atlanta, GA: Rodopi, 1992. p. 139-56.

COSTAMAGNA, Alejandra. El sistema del tacto. Barcelona: Anagrama, 2018.

COSTAMAGNA, Alejandra. Ponerse en el pellejo del otro. Entrevista a Daniel Hidalgo. Biblioteca Viva. 11 jun. 2019. Disponível em: https://bibliotecaviva.cl/alejandra-costamagna-ponerse-en-el-pellejo-del-otro/. Acesso em: 10 out. 2021.

GAMBARO, Griselda. El mar que nos trajo. Buenos Aires: Editorial Norma, 2001.

HALL, Stuart. The Question of Cultural Identity. Modernity and its Futures: Understanding Modern Societies. Book IV. In: MCGREW, Tony; HALL, Stuart; HELD, David (orgs.). Cambridge; England: Polity; Open UP, 1992. p. 274-316.

HIRSCH, Marianne. Family Frames: Photography, Narrative, and Postmemory. Cambridge, Mass.: Harvard UP, 1997.

HIRSCH, Marianne. The Generation of Postmemory: Writing and Visual Culture After the Holocaust. New York: Columbia UP, 2012.

HUNSACKER, Steven V. Autobiography and National Identity in the Americas. Charlottesville; London: UP of Virginia, 1999. 
HUTCHEON, Linda. The Postmodern Problematizing of History. ESC: English Studies in Canada, v. 14, n. 4, p. 365-382, 1988. Disponível em: https://doi.org/10.1353/esc.1988.0057. Acesso em: 27 set. 2014.

JAFFE, Noemi. What are the Blind Men Dreaming? Tradução de Julia Sanches e Ellen Elias Bursac. Dallas: Deep Vellum, 2016.

KAMINSKY, Amy. After Exile: Writing the Latin American Diaspora. Minneapolis: University of Minnesota Press, 1999.

LEVINE, Annette H. Cry for Me, Argentina: The Performance of Trauma in the Short Narratives of Aída Bortnick, Griselda Gambaro, and Tununa Mercado. Madison; Teaneck: Farleigh Dickinson UP, 2008.

MACHADO, Ana Maria. O mar nunca transborda. 2 ed. Rio de Janeiro: Nova Fronteira, 2008.

MONTES GARCÉS, Elizabeth. Introduction. In: GARCÉS, Elizabeth Montes (org.). Relocating Identities in Latin American Cultures. Calgary, Alberta: Calgary UP, 2007. p. 1-11.

PERREAULT, Jeanne. “Autography/Transformation/Asymmetry." In: SMITH, Sidonie; WATSON, Julia (orgs.). Women, Autobiography, Theory: A Reader. Madison: University of Madison Press, 1998. p. 19096.

SMITH, Sidonie; WATSON, Julia. Reading Autobiography: A Guide for Interpreting Life Narratives. 2 ed. Minneapolis; London: University of Minnesota Press, 2010.

SMITH, Sidonie; WATSON, Julia. Introduction: Situating Subjectivity in Women's Autobiographical Practices. In: SMITH, Sidonie; WATSON, Julia (orgs.). Women, Autobiography, Theory: A Reader. Madison: University of Madison Press, 1998. p 3-52.

VIEIRA, Ilma Socorro Gonçalves. O diálogo entre literatura e história na obra de Ana Maria Machado. In: GONÇALVES, Maria Teresa; ANTUNES, Benedito (eds.) Trança de histórias: a criação literária de Ana Maria Machado. São Paulo: UNESP, 2004. p. 35-52.

WILLIAMS, Raymond. The Postmodern Novel in Latin America. New York: St Martin's, 1995. 